\title{
Obituaries
}

\section{Colin McEvedy}

Psychiatrist who reinterpreted the Royal Free fatigue epidemic and wrote historical atlases

Colin McEvedy was interested in mass movements of people, whether as a psychiatrist, historian, or demographer, but it was his analysis of a mystery illness at the Royal Free Hospital in London that made his name in psychiatry. In 1955 an epidemic swept through the nursing staff at the Royal Free, closing the hospital for three months. In all, 300 people were affected, 200 of whom were admitted. No one died and not one single hospital patient was affected, and no causative organism was ever found, though not for want of looking. The disease was described as a benign, myalgic form of encephalomyelitis.

Fifteen years later, Colin McEvedy, then a senior registrar at the Middlesex Hospital, co-wrote two papers (with his boss, Professor Bill Beard), arguing, firstly, that the epidemic was one of conversion hysteria triggered by fear, probably of polio (BMJ 1970;1(687):711 , which was still a serious problem at the time; and, secondly, that it was one of several reported similar epidemics, others of which were among hospital nurses (BMJ 1970;1(687):11-15).

McEvedy was meanwhile writing a thesis on two epidemics of mass hysteria in girls' schools. His doctoral thesis was accepted without difficulty, but the papers on the Royal Free outbreak were greeted with howls of rage. Although he and Beard emphasised that the diagnosis of hysteria was "not a slur on the individuals or the institution involved" and that "the hysterical reaction is part of everyone's potential," many people, it seemed, felt that while hysteria was an acceptable diagnosis in the case of schoolgirls, it was not in the case of nurses.

McEvedy and Beard's argument was that, in addition to the absence of an identifiable causative organism, most people recovered unremarkably, and most biochemical tests were normal. Most sufferers had depression, fatigue, and vague neurological signs. Many had paralysis or sensory disturbances, but their reflexes were normal. Taking the institution as a wholestaff, students, and patients-the epidemic affected $10.4 \%$ of women and only $2.8 \%$ of men. Two sufferers who died from other causes (ovarian cancer, disseminated

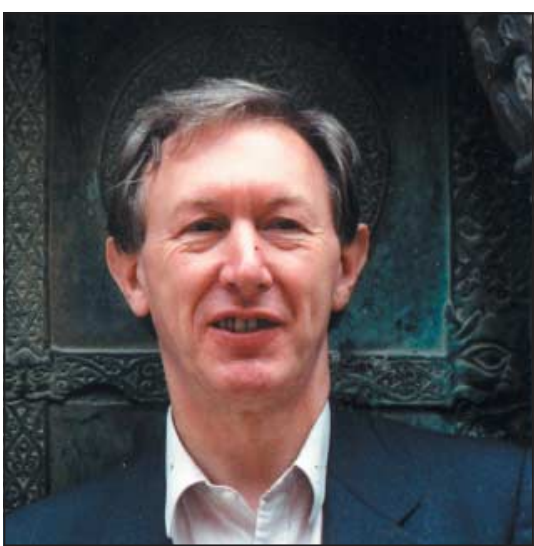

sclerosis) showed no pathological changes The symptoms were comparable to those of the schoolgirl epidemics that McEvedy had studied. In the second paper, he and Beard showed that eight hospital outbreaks-including that at the Royal Free-and seven other community outbreaks were essentially similar and that the concept of benign myalgic encephalomyelitis would be better named benign myalgia.

McEvedy and Beard's papers were greatly criticised, though they were never contradicted.

As a schoolboy, McEvedy's passion was the classical world, and he probably studied medicine only because his father was a well known surgeon. He was born in Salford and shone at Harrow School, winning a scholarship to Magdalen College, Oxford, where he kept a pet python. He did his clinical studies at Guy's, moving into his room complete with python, and gave the animal to the zoo after an ultimatum from his first wife, shortly before the birth of his first child.

After doing the obligatory year on the wards he did his national service at the Royal Air Force establishment in Farnborough, researching while there the effects of oxygen deprivation in high flying pilots.

In 1960 he went to the Maudsley for his psychiatry training, where he so impressed Sir Aubrey Lewis, its famed director, that Lewis invited him to join the professorial unit. After completing his diploma in psychological medicine he went to the Middlesex Hospital. He was appointed consultant psychiatrist at St Bernard's, a Victorian asylum, and at Ealing in 1972, and held both posts until his retirement in 1995. During this time he pioneered the movement of most of the St Bernard's patients to the community, and set up a new acute unit where patients had their own rooms.

In addition to his research on hysteria, Colin McEvedy was the author of a number of important atlases of historical demography, and papers and book chapters on bubonic plague and polio in history. Among his books are the Penguin atlases of medieval history and ancient history (both published when he was a registrar at the Maudsley), African history, modern history, European history, and the atlas of world population history. In all, he published more than a dozen history books, most of which are still in print. His two careers, psychiatry and history, ran in parallel and he succeeded in both by making good use of his time, and by turning down social invitations that didn't promise intellectual nourishment

McEvedy was a polymath, whom his friends used as a walking encyclopaedia for the things they couldn't find in Britannica or on Google; these included, said a friend, the cataloguing system in Caracalla's library or the population of Yucatan at the time of the Toltecs. He was mild mannered, modest, unflappable, witty, and without "side."

He never regretted not studying history at university, preferring to approach it his way. After a slow start, he became accepted, then respected, and finally revered by professional historians.

Divorced from his first wife, Jenny McKinnon Wood, and predeceased by his second wife and co-author, Sarah Leakey, he leaves three daughters. [Caroline Richmond]

Colin Peter McEvedy, consultant psychiatrist St Bernard's and Ealing hospitals, west London, 1972-95 (b Salford 1930; q Oxford/Guy's Hospital, London, 1955; DPM, DM, FRCPsych), died from myelofibrosis on 1 August 2005. 


\section{Hugh Bannerman}

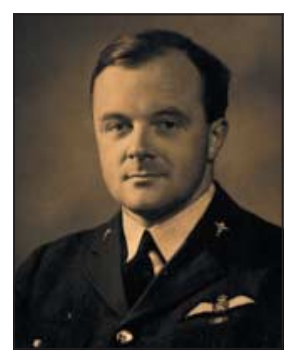

Former ophthalmologist Bristol (b Stanhope in Weardale 1908; q Durham 1931;DOMS), died from bronchopneumonia on 1 March 2005.

After house jobs Hugh Bannerman took a commission with the medical branch of the Royal Air Force in 1934. He obtained his pilot's licence before being sent to the Sudan and Palestine. Posted to France in the autumn of 1939, he was among the last to leave the country in June 1940 through Brest. He was severely injured in 1944 by an American army truck driven at night on the wrong side of the road, which left him disabled. On discharge from the RAF in 1953, he took up ophthalmology, initially in Sunderland and then in Bristol in the school ophthalmic service, as a clinical assistant at the Bristol Eye Hospital, and as an ophthalmic medical practitioner. He leaves a wife, Hilda. [Vincent J Marmion]

Hugh Bannerman's self-written obituary is available on bmj.com

\section{Tina Chan}

Consultant anaesthetist King's College Hospital,London (b 1966; q Dundee 1990; FRCA), died from breast cancer on 26 August 2004.

Tina worked almost entirely at or around King's throughout her career. She was straightforward in all interactions and never put on airs or graces. Almost at the end of her training Tina was diagnosed as having breast cancer. She went through surgery with the minimum of time off sick, followed by radiotherapy and chemotherapy, when she mostly continued to work. Tina went on to be appointed as a consultant at King's and had a special interest in obstetric anaesthesia. She was in her element on the labour ward and loved getting research and audit projects going. However, the breast cancer recurred. Against all odds Tina made it back to work for a few months in 2004. She leaves a husband, Wei, and a son. [PHILIPPA Groves]

\section{Richard Farrow}

Consultant radiologist Royal Cornwall Hospital 1995-2004 (b Newquay 1962; q Charing Cross Hospital, London, 1986; MRCP,FRCR), died from hypertrophic cardiomyopathy on 5 April 2004.

Richard trained in radiology in the south west before undertaking a fellowship at

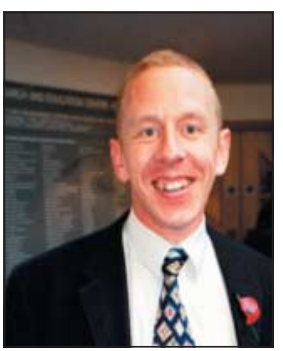

McMaster in Canada. During this period he developed an enthusiasm for medical education and particularly problem based learning (PBL), which ultimately led to his appointment in 2002 as the first director of PBL at the Peninsula Medical School. He was appointed as a consultant gastrointestinal radiologist in Truro in 1995 and latterly divided his time between his twin enthusiasms of medical education and abdominal radiology. He leaves a wife, Vicky, and two children. [Giles Maskell, Alan FreEman]

\section{Arthur Oliver Nixon Morris}

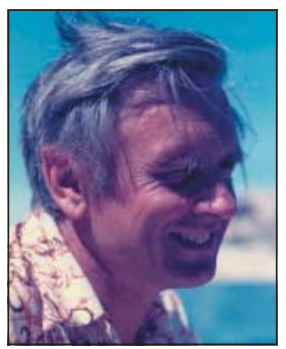

Former general practitioner Plymouth (b Plymouth 1926; q The London Hospital 1954), died from prostate cancer on 9 July 2005.

Arthur joined the Royal Navy in 1944, and spent time on the cruiser HMS Jamaica in the Atlantic and Indian oceans. He did his preregistration house jobs in Southampton and Dewsbury. After several years as an assistant without view he took on a singlehanded general practice in Station Road, Keyham, Plymouth, in 1960. His enormous creative urge found expression in the construction of superb model craft of all sizes, from fishing boats to aircraft carriers. In an upper room of the family home he created an entire dockyard for his ships. Much of his time was also taken making beautiful wooden carvings. Predeceased by his first wife, Rachel, he leaves his second wife, Judy; three children; and seven grandchildren. [GEOFFrey Morris]

\section{Andrew Douglas Scott}

Consultant in anaesthesia and intensive care medicine Royal Bournemouth NHS Trust (b London 1959; q St Thomas's Medical School 1983; FRCA), d 21 January 2005.

Andrew Scott did specialist training in Edinburgh, Manchester, London, and Wessex,

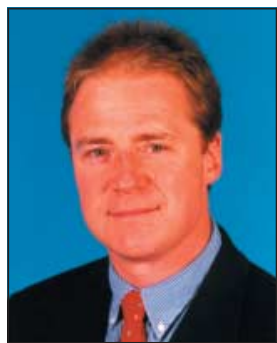

and undertook research in cardiothoracics. He was appointed a consultant anaesthetist in Poole and Bournemouth in 1995, becoming director of critical care in Bournemouth in 2001. He guided the critical care unit through a period of huge change, encompassing the doubling of the number of beds, the appointment of three additional colleagues, and the introduction of medical trainees into the unit. In January 2005 Andrew suffered from acute mental exhaustion and, completely unexpectedly, took his own life. He leaves a wife, Kay, and three children. [Martin Schuster-Bruce, Colin BERRY]

\section{John David Williams}

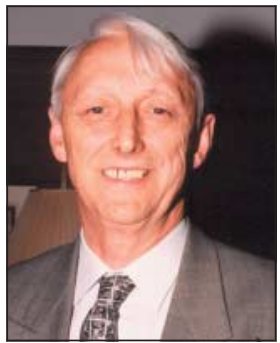

Former professor of medical microbiology London (b 1931; q Liverpool 1956; MD, FRCPath, FRCP), d 11 July 2005.

David Williams trained as a laboratory technician before qualifying in medicine. In 1965 he became consultant clinical microbiologist at Dudley Road Hospital, Birmingham, where he founded an antibiotic research laboratory, the first of its kind in the country, focusing on the emerging problems of resistance and also the use, and misuse, of antibiotics. In 1974 he was appointed to the Goldsmiths' chair of medical microbiology at the London Hospital Medical College, where he remained for 22 years until he retired. $\mathrm{He}$ was also civilian consultant in microbiology to the Royal Navy. David was the driving force behind the foundation of several infection societies in the United Kingdom. $\mathrm{He}$ was also secretary general, and subsequently president, of the International Society of (antimicrobial) Chemotherapy. [Alasdair Geddes, Norman SimMONS]

Longer versions of these obituaries are available on bmj.com 